\title{
Parathyroid Hormone-Related Changes of Bone Structure
}

\author{
Martin KUŽMA ${ }^{1}$, Peter JACKULIAK ${ }^{1}$, Zdenko KILLINGER ${ }^{1}$, Juraj PAYER ${ }^{1}$ \\ ${ }^{1} 5^{\text {th }}$ Department of Internal Medicine, Comenius University Faculty of Medicine, University \\ Hospital Bratislava, Slovakia
}

Received February 1, 2021

Accepted September 2, 2021

\section{Summary}

Parathyroid hormone (PTH) increases the release of serum calcium through osteoclasts, which leads to bone resorption. Primary, PTH stimulates osteoblasts leading to increase RANKL (receptor activator for nuclear factor kappa-B ligand) expression and thus differentiation of osteoclasts. In kidneys, PTH increases calcium and decrease phosphate reabsorption. In kidneys, PTH stimulates 1alpha-hydroxylase to synthesize active vitamin D. Primary hyperparathyroidism (PHPT) is characterized by skeletal or renal complications. Nowadays, the classical form of PHPT is less seen and asymptomatic or subclinical (oligo symptomatic) forms are more frequent. Previously, it was thought that cortical bone is preferably affected by PHPT and that predispose bones to fracture at sites with a higher amount of cortical bone. However, an increased risk of vertebral fractures has been found by most of the studies showing that also trabecular bone is affected. Bone Mass measurement (BMD) at all skeletal sites is advised, but another specific tool for fracture assessment is needed. Trabecular bone score (TBS), an indirect measure of trabecular bone, maybe a useful method to estimate fracture risk. TBS is associated with vertebral fractures in PHPT regardless of BMD, age, BMI and gender. Furthermore, there is an association between TBS and high resolution peripheral quantitative computed tomography (HR-pQCT) parameters in the trabecular and cortical compartment. However, studies considering the effect of PHPT treatment on TBS are more conflicting. Secondary hyperparathyroidism caused by vitamin D deficiency was associated with impaired bone microarchitecture in all age categories, as measured by TBS and Hr-pQCT with further improvement after treatment with vitamin $\mathrm{D}$.

\section{Key words}

Primary hyperparathyroidism - Vitamin D - Cortical bone • Trabecular bone $\bullet$ Trabecular bone score

\section{Corresponding author}

Martin Kužma, $5^{\text {th }}$ department of Internal Medicine, Comenius University Faculty of Medicine, University Hospital Bratislava, Ružinovská 6, 82606 Bratislava, Slovakia. Email: martin.kuzma@fmed.uniba.sk

\section{Parathyroid hormone actions}

Parathyroid hormone $(\mathrm{PTH})$ is a calcium and phosphate metabolism-regulating hormone. PTH is the product of the parathyroid glands. (Naylor et al. 1983). In target tissue, PTH interacts with G-protein and hisreceptor called the PTH/PTHrP receptor type 1 (PTH1R) (Jüppner et al. 1991). The main role of PTH consists of $\mathrm{Ca}^{2+}$ and phosphate regulation of extracellular fluid. The main regulator of PTH release is $\mathrm{Ca}^{2+}$, which through the binding to $\mathrm{Ca}$ sensing receptor in parathyroid glands inhibits PTH secretion. In contrast, a decrease of $\mathrm{Ca}^{2+}$ in extracellular fluid leads to stimulation of PTH release from the parathyroid gland. PTH afterwards stimulates the kidney (in distal nephron) to reabsorb $\mathrm{Ca}^{2+}$ (together with magnesium) and inhibit the reabsorption of phosphate and bicarbonate (Goltzman 2018) (Fig. 1).

Mineralization of bone tissue through the proliferation of mesenchymal stem cells is caused by binding PTH to PTH1R on cells of the osteoblastic lineage (Rouleau et al. 1990) and this leads to the production of the tumor necrosis factor-related cytokine, receptor activator of nuclear factor k-B (RANK) ligand (RANKL) and osteoprotegerin (OPG) thus accelerating bone resorption. As the result of hydroxyapatite degradation, $\mathrm{Ca}^{2+}$ and phosphate are released. PTH acts also on osteocytes in the bone matrix, inhibits releasing of sclerostin, resulting in new bone production (Fig. 2). 
The balance between bone formation versus bone resorption determines whether PTH has an anabolic or

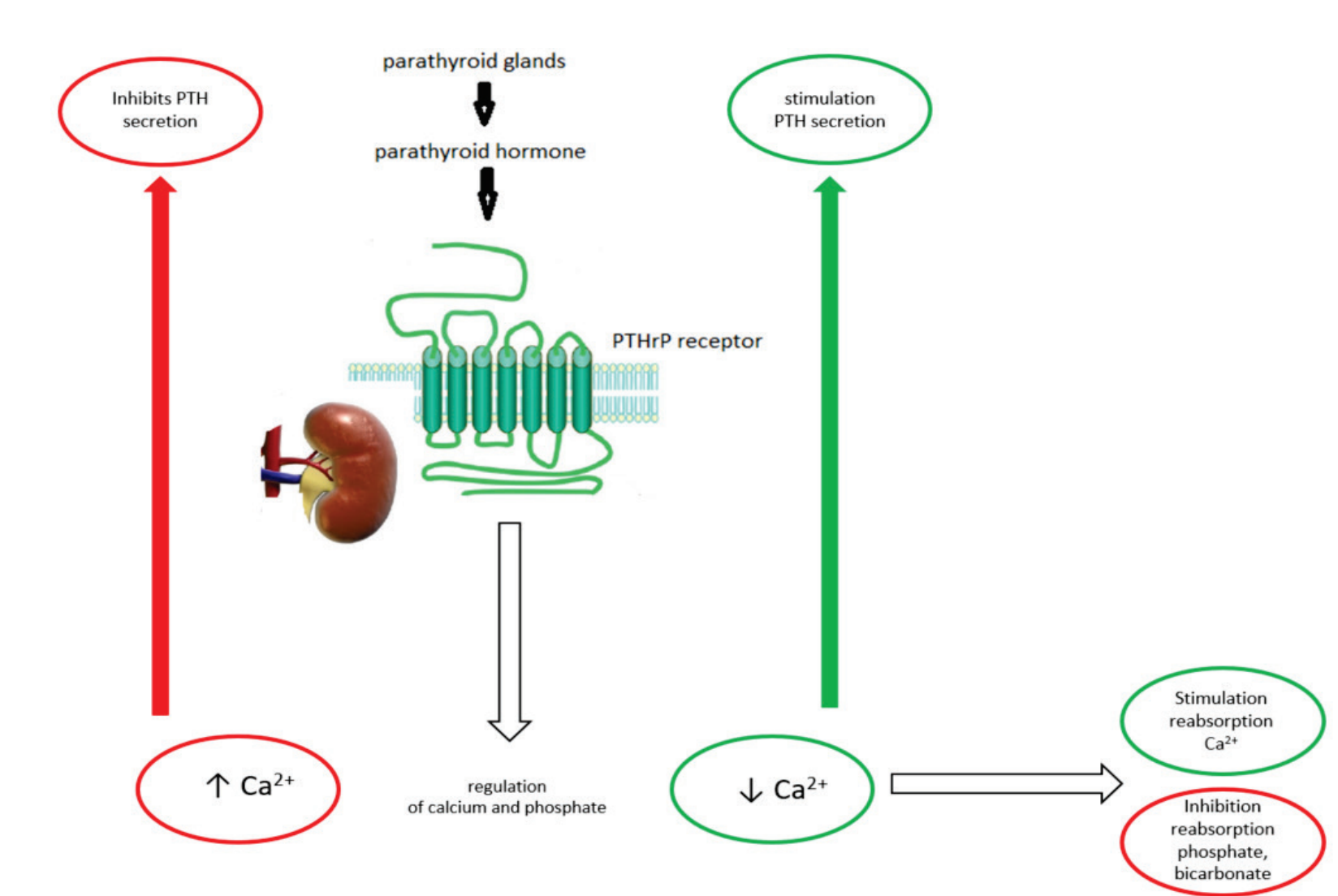

catabolic effect (Li et al. 2007, Yang et al. 2007).

Fig. 1. Main role of parathormone in kidney.

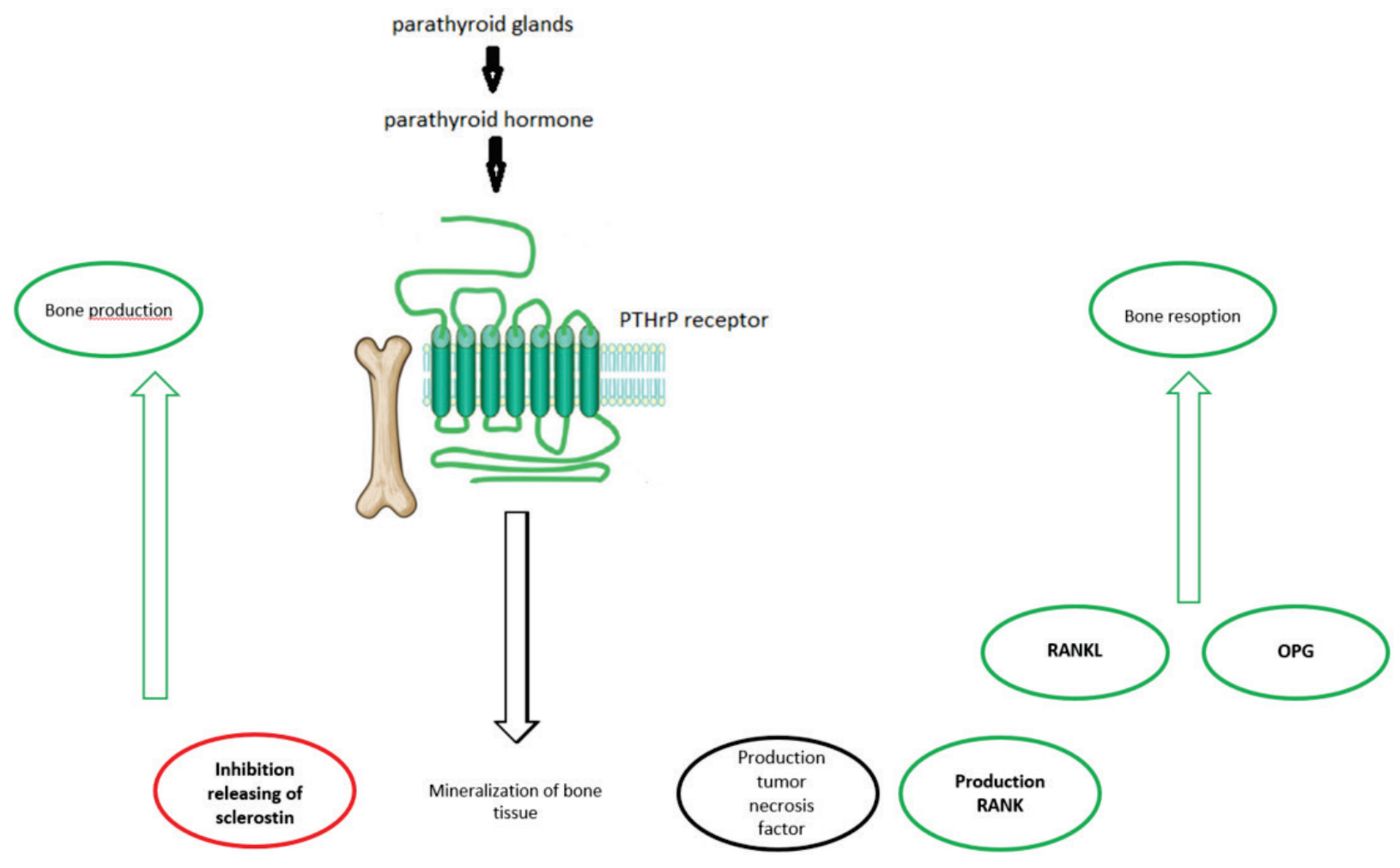

Fig. 2. Main role of parathormone in bone. 
This osteoanabolic effect is used in the administration of PTH in humans to treat severe osteoporosis and it is called "anabolic window." This mechanism of bone formation without resorption stimulation may lead to more than $20 \%$ increase in newly created trabecular and cortical bone (Girotra et al. 2006, Lindsay et al. 2006).

In the kidney, PTH together with hypocalcemia using 25-hydroxyvitamin D-1 $\alpha$ hydroxylase enzyme lead to the conversion of 25 -hydroxyvitamin D (25[OH]D) to active metabolite $1,25(\mathrm{OH}) 2 \mathrm{D}$ which increases intestinal absorption of $\mathrm{Ca}^{2+}$.

\section{PTH related changes in bone structure}

Bone manifestations of primary hyperparathyroidism (PHPT) as described as "osteitis fibrosa cystica" are nowadays not frequent as in past. The reason is that biochemical screening for serum calcium has widely become a routine (Misiorowski et al. 2017). Thus, most patients diagnosed with PHPT do not show overt skeletal or renal complications. Asymptomatic forms are much more frequent and became a problem for diagnostics and further management. In addition, cases with normal calcium but elevated levels of PTH are increasing. Thus, for a rheumatologist, it is important to define the impact of hyperparathyroidism, whether primary or secondary, on the bone measures during osteoporosis work-up.

Excluding secondary hyperparathyroidism due to vitamin D deficiency is important to avoid the undesirable effects of PHPT on bone turnover. Therefore measuring 25-hydroxyvitamin D (25[OH]D) in all PHPT patients and supplementing those with low levels (defined as $\leq 20 \mathrm{ng} / \mathrm{ml}$ or $50 \mathrm{nmol} / \mathrm{l}$ ) is important for further management (Eastell et al. 2014).

Despite oligosymptomatic or asymptomatic PHPT bone involvement by dual-energy X-ray absorptiometry (DXA) could be detected (Bandeira et al. 2014). One of the main DXA findings is bone mineral density (BMD) reduction at the distal radius, composed primarily of cortical bone. On the other site, lumbar spine BMD, a predominantly trabecular site, is preserved (Silverberg et al. 1999). This was supported by bone biopsy studies confirming cortical bone reduction and trabecular bone preservations in PHPT subjects in comparison to controls. However, recent research shows also trabecular bone seems to be affected as assessed using the trabecular bone score (TBS), an indirect DXA derived tool to define trabecular bone microstructure (Eller-Vainicher et al. 2013). According to this data, it is important to understand the pitfalls of PTH related bone changes and consequent fracture risk.

\section{Bone mineral density}

According to previous densitometry studies, it was thought that cortical bone is preferably affected by PTH and that predispose bones to fractures at sites with a higher amount of cortical bone in PHPT. Thus, measurement of BMD at $1 / 3$ distal radius was recommended to screen patients at risk of fractures. Importantly, a 15-year follow-up of asymptomatic PHPT patients without parathyroid surgery has shown that LS BMD did not change over this period but the decrease in hip and distal radius was observed (Rubin et al. 2008). However, this study was limited by the fact that only six patients demonstrated progressive decreases in BMD during the last five years. This leads to the conclusion, that long-term monitoring is essential for PHPT not undergoing surgery (Khan et al. 2017). Since PHPT is common in postmenopausal women, BMD findings are at least partially affected by estrogen deficiency, these factors have to be taken into account.

On the other site, increased risk of vertebral fractures (VF) has been found by most of the studies (Khosla et al. 1999, Geronimo et al. 2006, Vignali et al. 2009) showing that also trabecular bone is probably equally affected in PHPT and supported by prospective studies in which lower rate of vertebral fracture after parathyroidectomy in comparison to no surgery was observed (Lundstam et al. 2015). A significant predictor of fractures are increasing age and female gender (Bilezikian et al. 2014). It was assumed that changes in both compartments of bone microarchitecture contribute to increased fracture risk and BMD alone is not a sufficient tool for fracture prediction.

\section{Bone microstructure assessment}

Although the high-resolution peripheral quantitative computed tomography (HR-pQCT) and bone biopsy are predominantly experimental and not widely available tools, they are specific and most accurate methods for assessing bone microstructure.

Bone histomorphometry as the invasive method is of use to the assessment of the quantity of bone remodelling and structure. It can provide the 
determination of disease states and treatment effects. Bone histomorphometry can be applied to bone histological sections or high-resolution images produced by techniques such as microCT (Compston et al. 2018).

Bone biopsy was used to assess bone microstructure in PTH by few previous studies. In these studies (Parisien et al. 1995, Dempster et al. 1999) reduced cortical width and increased cortical porosity and no changes in trabecular bone structure were found, with no indications of an accelerated bone loss (Table 1). This is an issue among estrogen-deficient postmenopausal women with accelerated loss of trabecular bone.

The effect of parathyroid surgery in PHPT subjects after 6-12 months showed doubling in the activation frequency resulting in high bone turnover. PHPT surgery led to significant changes in cortical bone (Brockstedt et al. 1995).

HR-pQCT as the non-invasive method is very useful to measure the bone structure and helps to understand the pathogenesis of osteoporosis and the treatment mechanism (Zhou et al. 2016). Nevertheless, studies using HRpQCT for assessment of bone microarchitecture in untreated PHPT females in comparison to healthy age-matched controls has been demonstrating that bone abnormalities in PHPT are present in both compartments (Hansen et al. 2010, Stein et al. 2013). These studies reported reduced cortical area, total cortical volume, and cortical thickness at the radius as well as a reduced trabecular number, trabecular volume and increased trabecular separation. This was not so prominent at the tibia, possibly due to mechanical loading accounting for these differences (Table 1). Significant changes in both compartments, in cortical and trabecular geometry, density, 1-year surgery were observed (Hansen et al. 2012). However, it is unlikely that HR-pQCT will be the new "gold standard" method replacing DXA as the daily routine diagnostic tool.

In the light of new knowledge trabecular bone score (TBS) as a non-invasive method derived from the lumbar spine, DXA images seem promising for better estimation of fracture risk, especially for secondary osteoporosis. TBS is associated with trabecular microarchitecture and bone strength measured by HRpQCT. A low TBS value is associated with a smaller amount of well-connected and more widely distant trabeculae. High TBS values are determinants of better trabecular structure. It is well documented that low TBS is associated with a higher risk of fracture regardless of BMD (Hans et al. 2011, Boutroy et al. 2013, Briot et al. 2013, McCloskey et al. 2016). This particularly was observed in other cases of secondary osteoporosis such as diabetes mellitus (Leslie et al. 2013, Jackuliak and Payer 2014), endogenous hyperthyroidism in pre-menopausal women (Kuzma et al. 2018) or glucocorticoid-induced osteoporosis (Leib and Winzenrieth 2016).

In PHPT, at least partially degraded TBS despite normal spine BMD was observed. Furthermore, among PHPT patients, TBS was associated with HR-pQCT

Table 1. Bone changes in primary hyperparathyroidisim according to methods of assessement.

\begin{tabular}{|c|c|c|c|}
\hline Method & Cortical compartment & Trabecular compartment & $\begin{array}{c}\text { Effect of parathyroid } \\
\text { surgery }\end{array}$ \\
\hline$D X A$ & $\begin{array}{c}\downarrow \downarrow \downarrow \text { BMD at distal radius } \\
\downarrow \text { hip BMD }\end{array}$ & \pm in postmenopausal females & $\uparrow \uparrow \mathrm{BMD}$ at all sites \\
\hline \multirow[t]{2}{*}{ histomorphometry } & $\begin{array}{l}\downarrow \text { cortical width } \\
\uparrow \text { cortical porosity }\end{array}$ & - & $\begin{array}{c}\uparrow \text { doubling in activation } \\
\text { time }\end{array}$ \\
\hline & & & $\uparrow$ cortical parameters \\
\hline \multirow[t]{5}{*}{$H R-p Q C T$} & RADIUS & RADIUS & $\uparrow \uparrow$ both cortical and \\
\hline & $\downarrow$ cortical area, & $\downarrow$ trabecular number, & trabecular \\
\hline & $\begin{array}{c}\downarrow \text { total cortical volume, and } \downarrow \text { cortical } \\
\text { thickness }\end{array}$ & $\begin{array}{l}\downarrow \text { trabecular volume } \\
\uparrow \text { trabecular separation }\end{array}$ & compartments \\
\hline & TIBIA & TIBIA & \\
\hline & $\begin{array}{l}\text { No prominent effect (possibly due to } \\
\text { mechanical loading) }\end{array}$ & No prominent effect & \\
\hline$T B S$ & - & $\downarrow \downarrow$ lumbar spine TBS & Inconclusive \\
\hline
\end{tabular}


parameters at both measured sites, radius and tibia (Romagnoli et al. 2013, Silva et al. 2013). In the study of Eller-Vainicher et al. (2013) TBS was reduced in PHPT and associated with VF regardless of BMD, age, BMI and gender. In addition, TBS has been showing as an accurate tool for differentiation PHPT with VF in comparison to BMD. In addition, the combination of low TBS and low proximal femur BMD was most sensitive for the detection of VF patients. After 24 months of the follow-up, in patients who undergone parathyroid adenoma extirpation and increase of TBS, while in conservatively followed up patients no TBS change, was observed.

Considering that HR-pQCT is not a widely available and expansive method with higher radiation exposure, TBS is proving as a good tool for routine practice.

However, there are few studies where the positive effect of parathyroid surgery on TBS was not documented. One study observing the effect of surgery on BMD and TBS after surgery in obese versus non-obese PHPT subjects showed no increase in TBS at 24-month despite the increase in BMD, in both groups (Tay et al. 2018). The study was limited to only 15 subjects having complete data during the complete follow-up period. Similarly, in the most recent study of 32 patients 24-month after surgery, the effect on BMD was observed however the majority of patients were postmenopausal women, possibly affecting the results (Miguel et al. 2019).

Vitamin D deficiency is the frequent cause of secondary hyperparathyroidism and, in clinical settings, if not treated, it leads to osteomalacia. The impact of vitamin $\mathrm{D}$ on bone was discussed in many studies, and there are still several issues that should be solved. An important issue in the treatment of vitamin D deficiency is to find a target threshold of $25(\mathrm{OH}) \mathrm{D} 3$ levels to ensure sufficient skeletal health. One of the important studies assessing directly bone mineralization and its association with vitamin D levels at the tissue level has shown interesting results (Priemel et al. 2010). In the histomorphometric bone analysis of 675 iliac crest biopsies from the autopsy were performed. 25(OH)D3 levels greater than $75 \mathrm{nmol} / \mathrm{l}(30 \mathrm{ng} / \mathrm{ml})$ suggested that a minimum 25(OH)D3 serum level of $75 \mathrm{nmol} / \mathrm{l}$ $(30 \mathrm{ng} / \mathrm{ml})$ together with adequate calcium intake is needed to guarantee sufficient skeletal health. There are only a few studies concerning about effect of vitamin D deficiency-induced secondary hyperparathyroidism and its effect on bone microstructure. In one study 333 adolescents from Hong Kong were assessed for vitamin D levels and $64 \%$ were vitamin D insufficient with impaired cortical and trabecular HR-pQCT parameters when compared to vitamin D sufficient boys and girls (Cheung et al. 2016). In young Lebanese adults, the number of vitamin D insufficient subjects exceeds $60 \%$ and TBS is positively correlating in $25(\mathrm{OH}) \mathrm{D}$ with greater TBS in vitamin D sufficient participants (Alwan et al. 2018). In addition, among elderly people, cortical porosity was higher in those with the lowest quartile for vitamin D levels (Sundh et al. 2016). Taken all together, vitamin D through secondary elevated PTH has a significant impact on bone microstructure. In some studies, also supplementation with vitamin D led to bone quality improvement. In this study of 81 postmenopausal women dose of 2800 IU daily led to a decrease in PTH levels and significant improvement of trabecular bone, as measured by HR-pQCT (Bislev et al. 2019). Whether these findings are of benefit in reducing fracture risk needs further exploration.

\section{Conclusion}

In PTH-related disorders a novel method in combination with BMD or either alone to estimate the risk of future fractures is necessary. Several studies are utilizing HR-pQCT or bone histomorphometry to assess bone microarchitecture in PHPT or secondary hyperparathyroidism. However, these sophisticated methods due to invasiveness, cost or demanding staff are difficult to apply in routine clinical practice. At this point, TBS as a non-invasive, quick DXA-associated method appears useful in assessing the bone status and fracture risk. However, the implementation of this method in practice requires further exploration in clinical settings with fracture risk and treatment effect assessment.

\section{Conflict of Interest}

There is no conflict of interest.

\section{Acknowledgement}

Grant support: OPVaI ITMS2014+: 313012Q751 


\section{References}

ALWAN A, AL RASSY N, BERRO AJ, RIZKALLAH M, MATTA J, FRENN F, BACHOUR F, SEBAALY A, MAALOUF G, ZOUHAL H, EL HAGE R: Vitamin D and trabecular bone score in a group of young Lebanese adults. J Clin Densitom 21: 453-458, 2018. https://doi.org/10.1016/j.jocd.2018.02.002

BANDEIRA F, CUSANO NE, SILVA BC, CASSIBBA S, ALMEIDA CB, MACHADO VCC, BILEZIKIAN JP: Bone disease in primary hyperparathyroidism. Arq Bras Endocrinol Metab 58: 553-561, 2014. https://doi.org/10.1590/0004-2730000003381

BILEZIKIAN JP, BRANDI ML, EASTELL R, SILVERBERG SJ, UDELSMAN R, MARCOCCI C, POTTS JT, JR: Guidelines for the management of asymptomatic primary hyperparathyroidism: summary statement from the Fourth International Workshop. J Clin Endocrin Metab 99: 3561-3569, 2014. https://doi.org/10.1210/jc.20141413

BISLEV LS, LANGAGERGAARD RØDBRO L, ROLIGHED L, SIKJAER T, REJNMARK L: Bone microstructure in response to vitamin $\mathrm{d} 3$ supplementation: a randomized placebo-controlled trial. Calcified Tissue Int 104: 160-170, 2019. https://doi.org/10.1007/s00223-018-0481-6

BOUTROY S, HANS D, SORNAY-RENDU E, VILAYPHIOU N, WINZENRIETH R, CHAPURLAT R: Trabecular bone score improves fracture risk prediction in non-osteoporotic women: the OFELY study. Osteoporos Int 24: 77-85, 2013. https://doi.org/10.1007/s00198-012-2188-2

BRIOT K, PATERNOTTE S, KOLTA S, EASTELL R, REID DM, FELSENBERG D, GLUER CC, ROUX C: Added value of trabecular bone score to bone mineral density for prediction of osteoporotic fractures in postmenopausal women: the OPUS study. Bone 57: 232-236, 2013. https://doi.org/10.1016/j.bone.2013.07.040

BROCKSTEDT H, CHRISTIANSEN P, MOSEKILDE L, MELSEN F: Reconstruction of cortical bone remodeling in untreated primary hyperparathyroidism and following surgery. Bone 16: 109-117, 1995. https://doi.org/10.1016/8756-3282(95)80020-Q

COMPSTON J, SKINGLE L, DEMPSTER DW (2018) Chapter 53 - Bone Histomorphometry. In: Vitamin D (Fourth Edition), D FELDMAN (ed), pp 959-973: Acad Press. https://doi.org/10.1016/B978-0-12-809965-0.00053-7

DEMPSTER DW, PARISIEN M, SILVERBERG SJ, LIANG X-G, SCHNITZER M, SHEN V, SHANE E, KIMMEL DB, RECKER R, LINDSAY R, BILEZIKIAN JP: On the mechanism of cancellous bone preservation in postmenopausal women with mild primary hyperparathyroidism1. J Clin Endocrinol Metab 84: 1562-1566, 1999. https://doi.org/10.1210/jcem.84.5.5652

EASTELL R, BRANDI ML, COSTA AG, D'AMOUR P, SHOBACK DM, THAKKER RV: Diagnosis of asymptomatic primary hyperparathyroidism: proceedings of the Fourth International Workshop. J Clin Endocrinol Metab 99: 3570-3579, 2014. https://doi.org/10.1210/jc.2014-1414

ELLER-VAINICHER C, FILOPANTI M, PALMIERI S, ULIVIERI FM, MORELLI V, ZHUKOUSKAYA VV, CAIROLI E, PINO R, NACCARATO A, VERGA U, SCILLITANI A, BECK-PECCOZ P, CHIODINI I: Bone quality, as measured by trabecular bone score, in patients with primary hyperparathyroidism. Eur $\mathrm{J}$ Endocrinol 169: 155, 2013. https://doi.org/10.1530/EJE-13-0305

GERONIMO SD, ROMAGNOLI E, DIACINTI D, D'ERASMO E, MINISOLA S: The risk of fractures in postmenopausal women with primary hyperparathyroidism. Eur J Endocrinol 155: 415, 2006. https://doi.org/10.1530/eje.1.02225

GIROTRA M, RUBIN MR, BILEZIKIAN JP: The use of parathyroid hormone in the treatment of osteoporosis. Rev Endocr Metab Disord 7: 113-121, 2006. https://doi.org/10.1007/s11154-006-9007-z

GOLTZMAN D: Physiology of parathyroid hormone. Endocrinol Metab Clinics North Am 47: 743-758, 2018. https://doi.org/10.1016/j.ecl.2018.07.003

HANS D, GOERTZEN AL, KRIEG MA, LESLIE WD: Bone microarchitecture assessed by TBS predicts osteoporotic fractures independent of bone density: the Manitoba study. J Bone Miner Res 26: 2762-2769, 2011. https://doi.org/10.1002/jbmr.499

HANSEN S, BECK JENSEN J-E, RASMUSSEN L, HAUGE EM, BRIXEN K: Effects on bone geometry, density, and microarchitecture in the distal radius but not the tibia in women with primary hyperparathyroidism: A casecontrol study using HR-pQCT. J Bone Miner Res 25: 1941-1947, 2010. https://doi.org/10.1002/jbmr.98 
HANSEN S, HAUGE EM, RASMUSSEN L, JENSEN J-EB, BRIXEN K: Parathyroidectomy improves bone geometry and microarchitecture in female patients with primary hyperparathyroidism: A one-year prospective controlled study using high-resolution peripheral quantitative computed tomography. J Bone Miner Res 27: 1150-1158, 2012. https://doi.org/10.1002/jbmr.1540

CHEUNG TF, CHEUK KY, YU FWP, HUNG VWY, HO CS, ZHU TY, NG BKW, LEE KM, QIN L, HO SSY, WONG GWK, CHENG JCY, LAM TP: Prevalence of vitamin D insufficiency among adolescents and its correlation with bone parameters using high-resolution peripheral quantitative computed tomography. Osteoporosis Int 27: 2477-2488, 2016. https://doi.org/10.1007/s00198-016-3552-4

JACKULIAK P, PAYER J: Osteoporosis, fractures, and diabetes. Int J Endocrinol 820615, 2014. https://doi.org/10.1155/2014/820615

JÜPPNER H, ABOU-SAMRA AB, FREEMAN M, KONG XF, SCHIPANI E, RICHARDS J, KOLAKOWSKI LF, JR., HOCK J, POTTS JT, JR., KRONENBERG HM, ET AL.: A G protein-linked receptor for parathyroid hormone and parathyroid hormone-related peptide. Science 254: 1024-1026, 1991. https://doi.org/10.1126/science.1658941

KHAN AA, HANLEY DA, RIZZOLI R, BOLLERSLEV J, YOUNG JEM, REJNMARK L, THAKKER R, D'AMOUR P, PAUL T, VAN UUM S, SHRAYYEF MZ, GOLTZMAN D, KAISER S, CUSANO NE, BOUILLON R, MOSEKILDE L, KUNG AW, RAO SD, BHADADA SK, CLARKE BL, LIU J, DUH Q, LEWIECKI EM, BANDEIRA F, EASTELL R, MARCOCCI C, SILVERBERG SJ, UDELSMAN R, DAVISON KS, POTTS JT, JR., BRANDI ML, BILEZIKIAN JP: Primary hyperparathyroidism: review and recommendations on evaluation, diagnosis, and management. A Canadian and international consensus. Osteoporos Int 28: 1-19, 2017. https://doi.org/10.1007/s00198-016-3716-2

KHOSLA S, MELTON III LJ, WERMERS RA, CROWSON CS, O'FALLON WM, RIGGS BL: Primary hyperparathyroidism and the risk of fracture: A population-based study. J Bone Mineral Res 14: 1700-1707, 1999. https://doi.org/10.1359/jbmr.1999.14.10.1700

KUZMA M, VANUGA P, BINKLEY N, SAGOVA I, PAVAI D, BLAZICEK P, KUZMOVA Z, JACKULIAK P, VANUGA A, KILLINGER Z, PAYER J: High serum fractalkine is associated with lower trabecular bone score in premenopausal women with graves' disease. Horm Metab Res 50: 609-614, 2018. https://doi.org/10.1055/a-0633-2814

LEIB ES, WINZENRIETH R: Bone status in glucocorticoid-treated men and women. Osteoporos Int 27: 39-48, 2016. https://doi.org/10.1007/s00198-015-3211-1

LESLIE WD, AUBRY-ROZIER B, LAMY O, HANS D: TBS (trabecular bone score) and diabetes-related fracture risk. J Clin Endocrinol Metab 98: 602-609, 2013. https://doi.org/10.1210/jc.2012-3118

LI X, LIU H, QIN L, TAMASI J, BERGENSTOCK M, SHAPSES S, FEYEN JH, NOTTERMAN DA, PARTRIDGE NC: Determination of dual effects of parathyroid hormone on skeletal gene expression in vivo by microarray and network analysis. J Biol Chem 282: 33086-33097, 2007. https://doi.org/10.1074/jbc.M705194200

LINDSAY R, COSMAN F, ZHOU H, BOSTROM MP, SHEN VW, CRUZ JD, NIEVES JW, DEMPSTER DW: A novel tetracycline labeling schedule for longitudinal evaluation of the short-term effects of anabolic therapy with a single iliac crest bone biopsy: early actions of teriparatide. J Bone Miner Res 21: 366-373, 2006. https://doi.org/10.1359/JBMR.051109

LUNDSTAM K, HECK A, MOLLERUP C, GODANG K, BARANOWSKI M, PERNOW Y, VARHAUG JE, HESSMAN O, ROSEN T, NORDENSTROM J, JANSSON S, HELLSTROM M, BOLLERSLEV J: Effects of parathyroidectomy versus observation on the development of vertebral fractures in mild primary hyperparathyroidism. J Clin Endocrinol Metab 100: 1359-1367, 2015. https://doi.org/10.1210/jc.2014-3441

MCCLOSKEY EV, ODEN A, HARVEY NC, LESLIE WD, HANS D, JOHANSSON H, BARKMANN R, BOUTROY S, BROWN J, CHAPURLAT R, ELDERS PJM, FUJITA Y, GLUER CC, GOLTZMAN D, IKI M, KARLSSON M, KINDMARK A, KOTOWICZ M, KURUMATANI N, KWOK T, LAMY O, LEUNG J, LIPPUNER K, LJUNGGREN O, LORENTZON M, MELLSTROM D, MERLIJN T, OEI L, OHLSSON C, PASCO JA, RIVADENEIRA F, ROSENGREN B, SORNAY-RENDU E, SZULC P, TAMAKI J, KANIS JA: A meta-analysis of trabecular bone score in fracture risk prediction and its relationship to FRAX. J Bone Miner Res 31: 940-948, 2016. https://doi.org/10.1002/jbmr.2734 
MIGUEL GA, CARRANZA FH, RODRÍGUEZ JCR, RAMOS MA, PABLOS DL, HERRERO EF, DÍAZ-GUERRA GM: Trabecular bone score, bone mineral density and bone markers in patients with primary hyperparathyroidism 2 years after parathyroidectomy. Horm Metab Res 51: 186-190, 2019. https://doi.org/10.1055/a-0850-8679

MISIOROWSKI W, CZAJKA-ORANIEC I, KOCHMAN M, ZGLICZYNSKI W, BILEZIKIAN JP: Osteitis fibrosa cystica-a forgotten radiological feature of primary hyperparathyroidism. Endocrine 58: 380-385, 2017. https://doi.org/10.1007/s12020-017-1414-2

NAYLOR SL, SAKAGUCHI AY, SZOKA P, HENDY GN, KRONENBERG HM, RICH A, SHOWS TB: Human parathyroid hormone gene (PTH) is on short arm of chromosome 11. Somatic Cell Genet 9: 609-616, 1983. https://doi.org/10.1007/BF01574261

PARISIEN M, COSMAN F, MELLISH RWE, SCHNITZER M, NIEVES J, SILVERBERG SJ, SHANE E, KIMMEL D, RECKER RR, BILEZIKIAN JP, LINDSAY R, DEMPSTER DW: Bone structure in postmenopausal hyperparathyroid, osteoporotic, and normal women. J Bone Miner Res 10: 1393-1399, 1995. https://doi.org/10.1002/jbmr.5650100917

PRIEMEL M, VON DOMARUS C, KLATTE TO, KESSLER S, SCHLIE J, MEIER S, PROKSCH N, PASTOR F, NETTER C, STREICHERT T, PÜSCHEL K, AMLING M: Bone mineralization defects and vitamin D deficiency: histomorphometric analysis of iliac crest bone biopsies and circulating 25 -hydroxyvitamin $\mathrm{D}$ in 675 patients. J Bone Miner Res 25: 305-312, 2010. https://doi.org/10.1359/jbmr.090728

ROMAGNOLI E, CIPRIANI C, NOFRONI I, CASTRO C, ANGELOZZI M, SCARPIELLO A, PEPE J, DIACINTI D, PIEMONTE S, CARNEVALE V, MINISOLA S: "Trabecular Bone Score" (TBS): an indirect measure of bone micro-architecture in postmenopausal patients with primary hyperparathyroidism. Bone 53: 154-159, 2013. https://doi.org/10.1016/j.bone.2012.11.041

ROULEAU MF, MITCHELL J, GOLTZMAN D: Characterization of the major parathyroid hormone target cell in the endosteal metaphysis of rat long bones. J Bone Miner Res 5: 1043-1053, 1990. https://doi.org/10.1002/jbmr.5650051008

RUBIN MR, BILEZIKIAN JP, MCMAHON DJ, JACOBS T, SHANE E, SIRIS E, UDESKY J, SILVERBERG SJ: The natural history of primary hyperparathyroidism with or without parathyroid surgery after 15 years. J Clin Endocrinol Metab 93: 3462-3470, 2008. https://doi.org/10.1210/jc.2007-1215

SILVA BC, BOUTROY S, ZHANG C, MCMAHON DJ, ZHOU B, WANG J, UDESKY J, CREMERS S, SARQUIS M, GUO XD, HANS D, BILEZIKIAN JP: Trabecular bone score (TBS)--a novel method to evaluate bone microarchitectural texture in patients with primary hyperparathyroidism. J Clin Endocrinol Metab 98: 1963-1970, 2013. https://doi.org/10.1210/jc.2012-4255

SILVERBERG SJ, SHANE E, JACOBS TP, SIRIS E, BILEZIKIAN JP: A 10-year prospective study of primary hyperparathyroidism with or without parathyroid surgery. New England J Med 341: 1249-1255, 1999. https://doi.org/10.1056/NEJM199910213411701

STEIN EM, SILVA BC, BOUTROY S, ZHOU B, WANG J, UDESKY J, ZHANG C, MCMAHON DJ, ROMANO M, DWORAKOWSKI E, COSTA AG, CUSANO N, IRANI D, CREMERS S, SHANE E, GUO XE, BILEZIKIAN JP: Primary hyperparathyroidism is associated with abnormal cortical and trabecular microstructure and reduced bone stiffness in postmenopausal women. J Bone Miner Res 28: 1029-1040, 2013. https://doi.org/10.1002/jbmr.1841

SUNDH D, MELLSTRÖM D, LJUNGGREN Ö, KARLSSON MK, OHLSSON C, NILSSON M, NILSSON AG, LORENTZON M: Low serum vitamin D is associated with higher cortical porosity in elderly men. J Int Med 280: 496-508, 2016. https://doi.org/10.1111/joim.12514

TAY Y-KD, CUSANO NE, RUBIN MR, WILLIAMS J, OMERAGIC B, BILEZIKIAN JP: Trabecular bone score in obese and nonobese subjects with primary hyperparathyroidism before and after parathyroidectomy. J Clin Endocrinol Metab 103: 1512-1521, 2018. https://doi.org/10.1210/jc.2017-02169

VIGNALI E, VICCICA G, DIACINTI D, CETANI F, CIANFEROTTI L, AMBROGINI E, BANTI C, DEL FIACCO R, BILEZIKIAN JP, PINCHERA A, MARCOCCI C: Morphometric vertebral fractures in postmenopausal women with primary hyperparathyroidism. J Clin Endocrinol Metab 94: 2306-2312, 2009. https://doi.org/10.1210/jc.2008-2006 
YANG D, SINGH R, DIVIETI P, GUO J, BOUXSEIN ML, BRINGHURST FR: Contributions of parathyroid hormone (PTH)/PTH-related peptide receptor signaling pathways to the anabolic effect of PTH on bone. Bone 40: 1453-1461, 2007. https://doi.org/10.1016/j.bone.2007.02.001

ZHOU B, WANG J, YU YE, ZHANG Z, NAWATHE S, NISHIYAMA KK, ROSETE FR, KEAVENY TM, SHANE

E, GUO XE: High-resolution peripheral quantitative computed tomography (HR-pQCT) can assess microstructural and biomechanical properties of both human distal radius and tibia: Ex vivo computational and experimental validations. Bone 86: 58-67, 2016. https://doi.org/10.1016/j.bone.2016.02.016 